\title{
Free-choice grazing of native range and cool-season grasses
}

\author{
J. F. KARN AND R. E. RIES
}

Authors are Research Animal Scientist and Rangeland Scientist, USDA, Agricultural Research Service, Northern Great Plains Research Laboratory, P. O. Box 459, Mandan, N.D. 58554. This article is a contribution from USDA, Agricultural Research Service, Mandan, N.D.

Abstract

A grazing system which allows cattle to select a season-long diet more nearly meeting their nutrient requirements should facilitate optimal weight gains. A study was conducted near Mandan, N. D. comparing season-long weight gains of yearling steers free-choice grazing on composite pastures containing equal sized plots of 'Nordan' crested wheatgrass (Agropyron desertorum) (Fisch. Ex. Link) Schult.), 'Rodan' western wheatgrass (Pascopyrum smithii (Rydb.) Löve), 'Lincoln' smooth bromegrass (Bromus inermis Leyss.), and native range, to pastures containing the individual pasture types alone. The study was initiated in mid-May and terminated in early October each year from 1995-1997. Pastures were grazed at a stocking rate of 1.9 ha per steer for 147 days or 1.7 AUM ha ${ }^{-1}$. Steer behavior on composite pastures was recorded every $10 \mathrm{~min}$. from dawn to dusk 2 days per week each summer. In 1997, forage samples were clipped for chemical analysis at 4week intervals from all pasture types either within composite pastures or as individual pasture types. Only in 1996 were daily gains of steers on the free-choice treatment different $(P<0.10)$ from all other treatments. Over the 3-year study, daily gains for steers on the free-choice treatment $(1.11 \mathrm{~kg})$ were statistically equal to steers on smooth bromegrass $(1.04 \mathrm{~kg})$ and western wheatgrass $(1.00 \mathrm{~kg})$ and were significantly greater than daily gains on native range $(0.98 \mathrm{~kg})$ and crested wheatgrass $(0.97 \mathrm{~kg})$. Steers tended to spend a greater percentage of observation time grazing smooth bromegrass than the other 3 pasture types, especially early in the grazing season. The period of maximum grazing preference for the other pasture types was late in the season in 1995 and 1996 for crested wheatgrass, in mid-season in 1996 for native range, and late in the season in 1997 for western wheatgrass. Chemical analysis of forage samples collected in 1997 show that smooth bromegrass had the highest crude protein and in vitro dry matter digestibility, and the lowest neutral detergent fiber at all 3 summer grazing periods. Forage quality data and the preference of steers for smooth bromegrass help to explain why steers on this treatment had excellent daily gains, especially during early and mid-season.

Key Words: animal behavior, crested wheatgrass, western wheatgrass, smooth bromegrass

Mention of a trade name is solely to identify materials used and does not constitute endorsement by the U. S. Department of Agriculture. The authors wish to thank Mr. Richard Huppler and Mr. Curtis Klein for their assistance in conducting the research and Dr. Gary V. Richardson for advice and assistance with statistical procedures.

U.S. Department of Agriculture, Agriculture Research Service, Northern Plains Area, is an equal opportunity/affirmative action employer and all agency services are available without discrimination.

Manuscript accepted 24 Oct. 01.
Resumen

Un sistema de apacentamiento que permite al ganado seleccionar durante largo plazo una dieta muy cercana de llenar sus requerimientos nutricionales debe producir ganancias de peso óptimas. Se condujo un estudio cerca de Mandan, N.D. para comparar las ganancias de peso a largo plazo de novillos en apacentamiento a libre elección de praderas compuestas de parcelas de igual tamaño de "Crested wheatgrass" (Agropyron desertorum) (Fisch. Ex. Link) Schult.) variedad 'Nordan', "Western wheatgrass" (Pascopyrum smithii (Rydb.) Löve) variedad 'Rodan', 'Smooth bromegrass" (Bromus inermis Leyss.) variedad 'Lincoln' y pastizal nativo contra praderas individuales de las especies anteriores. El estudio se inicio a mediados de mayo y termino a inicios de octubre de cada año durante el período de 1995 a 1997. Las praderas fueron apacentadas con una carga animal de 1.9 ha novillo ${ }^{-1}$ durante 147 días o 1.7 UAM $\mathrm{ha}^{-1}$. El comportamiento de los novillos en las praderas compuestas se registro cada $\mathbf{1 0}$ minutos desde la salida hasta la puesta del sol, estas observaciones se realizaron en el verano durante dos días por semana. En 1997, tanto en las praderas compuestas como en las de especies individuales, se cortaron muestras de forraje para análisis químicos, el muestro fue a intervalos de 4 semanas. Solo en 1996 Las ganancias diarias de peso de los novillos del tratamiento de apacentamiento a libre elección fueron diferentes $(P<0.10)$ del resto de los tratamientos. En el periodo de 3 años del estudio Las ganancias diarias de los novillos en apacentamiento a libre elección $(1.11 \mathrm{~kg})$ fueron estadísticamente iguales a las de los novillos apacentando "Smooth bromegrass" $(1.04 \mathrm{~kg}) \mathrm{y}$ "Western wheatgrass" $(1.00 \mathrm{~kg})$ y fueron significativamente mayores que las ganancias diarias obtenidas en el pastizal nativo $(0.98 \mathrm{~kg})$ y en el "Crested wheatgrass" $(0.97 \mathrm{~kg})$. Los novillos tendieron a pasar un mayor porcentaje del tiempo de observación apacentando "Smooth bromegrass" que en los otros 3 tipos de pradera, especialmente a inicios de la estación de apacentamiento. El período de máxima preferencia para los otros tipos de pradera fue a fines de la estación de apacentamiento de 1995 y 1996 para el "Crested wheatgrass", a mediados de estación en 1996 para el pastizal nativo y a fines de la estación de 1997 para "Western wheatgrass". Los análisis químicos de las muestras de forraje colectadas en 1997 muestran que el "Smooth bromegrass" tuvo los mayores porcentajes de proteína cruda y digestibilidad in vitro de la materia seca y los mas bajos de fibra neutro detergente en los 3 períodos de apacentamiento en verano. Los datos de calidad de forraje y la preferencia de los novillos por el "Smooth bromegrass" ayudan a explicar porque los novillos en este tratamiento tuvieron excelentes ganancias diarias de peso, especialmente a inicios y mediados de la estación de apacentamiento. 
A grazing scheme providing cattle with adequate amounts of high quality forage throughout the grazing season should facilitate optimum season-long performance. Introduced cool-season grasses such as crested wheatgrass (Agropyron desertorum (Fisch. Ex. Link) Schult) and smooth bromegrass (Bromus inermis Leyss.) produce high quality forage that can be grazed much earlier in the spring than native range (Sarvis 1941, Williams and Post 1945). In mid-summer however, when reproductive tillers occur, forage quality and palatability decline (Rogler et al. 1962). If precipitation is adequate for regrowth, crested wheatgrass can also be grazed in the fall (Frischknecht et al. 1953). Total forage production from native range can be increased by deferring its use until mid-June (Campbell 1952).

Grazing systems utilizing seeded coolseason grasses for early season grazing and native range for mid-to-late summer grazing have been proposed by Campbell (1963), Lodge (1963), Currie (1969), and Lorenz (1977) to improve animal performance and enhance the long-term viability of native rangelands in the Northern Great Plains. However, complementary grazing systems require more fencing and increased management to rotate livestock among pastures. Free-choice grazing systems which would reduce these requirements have been proposed by Lodge (1963) and Smoliak (1968). With a freechoice system, ewes tended to rotate themselves among pasture types during the summer and produced weight gains comparable to rotational grazing (Smoliak 1968). The objective of the current research was to determine if weight gains of yearling steers could be improved by season-long free-choice grazing on composite pastures containing equal sized plots of crested wheatgrass, smooth bromegrass, western wheatgrass (Pascopyrum smithii (Rydb.) Löve), and native range compared to steers grazing these pasture types individually. A secondary objective was to estimate the amount of time steers on composite pastures spent grazing on each pasture type, to facilitate design of better free-choice grazing strategies in the future.

\section{Materials and Methods}

Grazing studies were conducted near Mandan, N.D. for 147 days each grazing season from 1995 to 1997 . Mandan $\left(46^{\circ}\right.$ $46^{\prime} \mathrm{N}, 100^{\circ} 55^{\prime} \mathrm{W}$ ) has a semi-arid climate with an elevation of $500 \mathrm{~m}$. Grazing periods were from 12 May to 6 October 1995;
10 May to 4 October 1996; and 15 May to 9 October 1997 . The study used replicate 24.4-ha composite pastures containing 6.1-ha plots of 'Nordan' crested wheatgrass, 'Rodan' western wheatgrass, 'Lincoln' smooth bromegrass, and native range. The native range contained blue grama (Bouteloua gracilis (H. B. K.) Griffiths), needleandthread (Stipa comata Trin. and Rupr.), green needlegrass (S. viridula Trin.), western wheatgrass, sedges (Carex spp.), threeawn (Aristida spp.) and Kentucky bluegrass (Poa pratensis L.). The 6.1-ha plots of the 4 pasture types were used in earlier grazing studies reported by Hofmann et al. (1993) and Karn et al. (1999). In the fall of 1994, following termination of the previous study, replicate composite pastures were established by removing fences which separated adjoining seeded pastures and adjacent plots of native range. Replicate individual 6.1-ha pastures of 'Nordan' crested wheatgrass, 'Rodan' western wheatgrass, 'Lincoln' smooth bromegrass and native range were also used. Hence, there were 5 pasture treatments with 2 replications for a total of 10 pastures. The 3 seeded species were established by no-till seeding into spring wheat (Triticum aestivum L.) stubble in the fall of 1985 (Hofmann et al. 1993). Pastures were located on fine-silty, mixed, superactive, frigid Pachic Haplustolls and fine-silty, mixed, superactive, frigid Typic Haplustolls soils and had not been fertilized for 10 years before or during the current study.

Composite and individual plots of the 4 pasture types were stocked with 12 and 3 yearling Hereford steers (Bos taurus), respectively. Initial steer weights averaged $300 \mathrm{~kg}$. Since composite pastures were 4 times as large as individual pasture type plots, they were stocked with 4 times as many steers to provide an equal stocking rate among treatments. Due to the presence of large exclosures within all treatment pastures the grazing area in composite pastures and individual pasture type plots were reduced to 22.8 and 5.7 ha respectively, which resulted in a stocking rate of 1.9 ha per steer for a 147-day grazing season, or 1.7 AUM ha-1.

Steers were weighed following an overnight stand without feed or water at the beginning and end of each grazing season and at 21-day intervals during the season. Trace mineralized block salt containing $92-98.5 \%$ salt, $0.35 \%$ zinc, $0.34 \%$ iron, $0.20 \%$ manganese, $0.033 \%$ copper, $0.007 \%$ iodine, and $0.005 \%$ cobalt was available at all times.
Steer behavior was observed on the 2 composite pastures every 10 minutes from dawn to dusk 2 days each week throughout each of the 3 grazing seasons. For each 10-minute observation period, the location and behavior of the steers were recorded. Behavior was recorded as grazing, standing, lying, scratching, playing, salting, drinking and walking. Observation days totaled 32 in 1995, 34 in 1996, and 38 in 1997. Within a season, data were grouped into early, mid-, and late grazing periods based on seasonal precipitation patterns.

In 1997, forage samples were collected from each pasture type within the composite pastures as well as from the individual pasture type plots at approximately 4week intervals. Hand clipped samples selected to simulate grazing (Karn and Hofmann 1990) were taken from each pasture by 3 individuals. To insure that pastures were sampled carefully, clippings were taken on 2 consecutive days so that clippers would have time to observe steer grazing patterns and sample accordingly. Collection dates were 29/30 May, 25/26 June, 23/24 July, 20/21 August, and 17/18 September. Following collection, forage samples were dried at $60^{\circ} \mathrm{C}$, ground through a $1-\mathrm{mm}$ screen, and analyzed for nitrogen using a Carlo Erba Model NA 1500 series 2 nitrogen/carbon/sulphur analyzer (CE Elantech, Inc., Lakewood, N.J. 08701). Crude protein was calculated by multiplying nitrogen by 6.25. Neutral detergent fiber (NDF), and true in vitro dry matter digestibility (IVDMD) were determined according to Goering and Van Soest (1970). An ANKOM fiber analyzer (Cherney et al. 1997) was used to facilitate measuring NDF in forage samples and forage residue following a 48-hour in vitro fermentation.

Daily precipitation and ambient minimum and maximum air temperatures were recorded at a weather station located 3.2 $\mathrm{km}$ north of the study site. Monthly precipitation totals and mean-monthly temperatures (minimum and maximum) were calculated and compared to historic values (Table 1).

Animal weight gain and forage quality data were analyzed using the SAS MIXED procedure (SAS Inst., Inc. 1996) with the replication(treatment) effect considered random. Least squares means were separated by the SAS PDIFF option. Animal behavior data were analyzed according to SAS GLM procedures (SAS Inst., Inc. 1985) and pasture type was tested with the replication(pasture type) term. Pasture type means for steer behavior data were separated by the Student-Newman-Keuls' test. Data were considered significant at $\mathrm{P}$ $<0.05$ unless otherwise indicated. 


\section{Results and Discussion}

\section{Steer performance}

Daily gains averaged over the 3 years tended to be higher for steers on the freechoice treatment, but free-choice treatment gains were only significantly $(\mathrm{P}<0.10)$ higher than native range and crested wheatgrass (Table 2).

Because of a year by treatment interaction, treatment average daily gains are presented by year as well as 3-yr averages (Table 2). Yearly differences in steer performance were likely related to precipitation amounts and distributions, which in turn affected forage growth patterns. Precipitation levels in 1995 were $52 \%$ above the 80 -year average (Table 1) and facilitated good forage growth throughout the summer. Steer weight gains in 1995 were above normal for our area and higher than gains in 1996 and 1997. Weight gains were comparable on free-choice and smooth bromegrass treatments and the free-choice treatment was significantly higher than western wheatgrass, native range, and crested wheatgrass. In 1996, daily gains on the free-choice treatment were greater $(\mathrm{P}<0.10)$ than any other pasture type (Table 2 ). Adequate early season precipitation (Table 1) facilitated abundant early cool-season forage growth, and above average late season precipitation promoted regrowth of cool-season grasses. Steers on the free-choice treatment had the option of grazing cool-season grasses in the spring and fall and native range in mid-summer, while steers grazing individual pasture types alone had little dietary choice. In 1997, daily gains among pasture treatments were not different $(\mathrm{P}<$ 0.10 ). Below average precipitation in May and June 1997 likely reduced early coolseason grass production which was detrimental to steer gain on the free-choice treatment. Observational data suggest that early season grazing pressure was greater on crested wheatgrass and smooth bromegrass in the free-choice system,

Table 1. Precipitation $(\mathrm{mm})$ and mean monthly ambient air temperatures $\left(\mathrm{C}^{\circ}\right)$ between April and October for 1995-1997 and the 80-year average for Mandan.

\begin{tabular}{|c|c|c|c|c|c|c|c|c|}
\hline & \multicolumn{4}{|c|}{ Precipitation } & \multicolumn{4}{|c|}{ Temperature } \\
\hline & 1995 & 1996 & 1997 & 80 -year av. & 1995 & 1996 & 1997 & 80 -year av. \\
\hline \multicolumn{5}{|c|}{$\ldots-\ldots(\mathrm{mm}) \ldots$} & \multicolumn{4}{|c|}{$\left.{ }^{\circ} \mathrm{C}\right)-1$} \\
\hline Apr. & 30 & 10 & 70 & 43 & 4 & 3 & 4 & 6 \\
\hline May & 173 & 59 & 16 & 57 & 11 & 11 & 12 & 13 \\
\hline Jun. & 66 & 60 & 44 & 75 & 19 & 19 & 20 & 18 \\
\hline Jul. & 152 & 102 & 94 & 60 & 21 & 20 & 23 & 22 \\
\hline Aug. & 43 & 44 & 27 & 49 & 22 & 22 & 21 & 20 \\
\hline Sep. & 30 & 85 & 28 & 41 & 14 & 14 & 16 & 14 \\
\hline Total & 494 & 360 & 279 & 325 & & & & \\
\hline
\end{tabular}

Table 2. Average daily gains \pm SE $(\mathrm{kg})$ of steers grazing free-choice and individual pasture types for 1995, 1996, 1997 and for all 3 years ${ }^{1}$.

\begin{tabular}{lccccc}
\hline \hline Treatment & $\begin{array}{c}\text { Steers/ } \\
\text { treat. }\end{array}$ & 1995 & 1996 & 1997 & 3-yr means \\
\hline Free-choice & 24 & $1.19^{\mathrm{a}} \pm 0.04$ & $1.15^{\mathrm{a}} \pm 0.04$ & $1.00^{\mathrm{a}} \pm 0.04$ & $1.11^{\mathrm{a}} \pm 0.04$ \\
Smooth bromegrass & 6 & $1.13^{\mathrm{ab}} \pm 0.06$ & $0.92^{\mathrm{b}} \pm 0.06$ & $1.06^{\mathrm{a}} \pm 0.06$ & $1.04^{\mathrm{ab}} \pm 0.04$ \\
Western wheatgrass & 6 & $1.05^{\mathrm{b}} \pm 0.06$ & $0.95^{\mathrm{b}} \pm 0.06$ & $1.02^{\mathrm{a}} \pm 0.06$ & $1.00^{\mathrm{ab}} \pm 0.04$ \\
Native range & 6 & $1.07^{\mathrm{b}} \pm 0.06$ & $0.92^{\mathrm{b}} \pm 0.06$ & $0.95^{\mathrm{a}} \pm 0.06$ & $0.98^{\mathrm{b}} \pm 0.04$ \\
Crested wheatgrass & 6 & $0.96^{\mathrm{b}} \pm 0.06$ & $0.91^{\mathrm{b}} \pm 0.06$ & $1.05^{\mathrm{a}} \pm 0.06$ & $0.97^{\mathrm{b}} \pm 0.04$ \\
Year LS means & & $1.12^{\mathrm{a}} \pm 0.02$ & $1.04^{\mathrm{b}} \pm 0.02$ & $1.01^{\mathrm{c}} \pm 0.02$ & \\
\hline
\end{tabular}

${ }^{1}$ Least squares means within a column among treatments and least squares means by year with different superscripts differ at $\mathrm{P}<0.10$.

because there were 4 times as many steers compared to the individual pasture type plots and steers spent a high percentage of grazing time on these species. Average daily gains for the free-choice treatment over the 3 years were statistically equal to daily gains on smooth bromegrass and western wheatgrass and higher $(\mathrm{P}<0.10)$ than gains on native range and crested wheatgrass.

Average cumulative weight gains per steer, by weighing period over the 3-year study (Fig. 1), show steers on the freechoice treatment tended to gain less in early and mid-season than steers on smooth bromegrass, but in August and September the free-choice treatment had higher daily gains $(\mathrm{P}<0.10)$ than steers on smooth brome and crested wheatgrass.

Cumulative weight gains during August and September also improved for steers on individual western wheatgrass and native range treatments and were not different $(P$
$>0.10$ ) from the free-choice treatment during this period (data not shown). Grazing steers on crested wheatgrass in the spring followed by free-choice grazing on crested wheatgrass and native range during the summer and fall has been reported to be a better system than freechoice grazing on crested wheatgrass and native range for the entire season (Lodge 1963). Perhaps weight gains in the current study could have been improved by grazing smooth bromegrass alone early in the season and free-choice grazing on composite pastures the rest of the season. Although early and mid-season weight gain differences between the free-choice and smooth bromegrass treatments were small and not significant, it seemed to be a consistent and perplexing phenomena. Perhaps steers on the free-choice treatment voluntarily grazed excessively on lower quality pasture types early in the season, or perhaps our composite pastures with

Table 3. Chemical composition of hand-collected forage samples in treatment pastures, $1997^{1}$.

\begin{tabular}{|c|c|c|c|c|c|c|c|c|c|}
\hline \multirow[b]{2}{*}{ Pasture type } & \multicolumn{3}{|c|}{ IVDMD $^{2}$} & \multicolumn{3}{|c|}{$\mathrm{CP}^{2}$} & \multicolumn{3}{|c|}{$\mathrm{NDF}^{2}$} \\
\hline & Early & Mid & Late & Early & Mid & Late & Early & Mid & Late \\
\hline & \multicolumn{3}{|c|}{ - } & \multicolumn{3}{|c|}{ 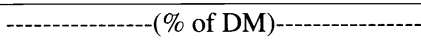 } & \multicolumn{3}{|c|}{ (\% of DM)- } \\
\hline Smooth bromegrass & $77.0^{\mathrm{a}}$ & $71.4^{\mathrm{a}}$ & $66.6^{\mathrm{a}}$ & $14.0^{\mathrm{a}}$ & $14.6^{\mathrm{a}}$ & $11.2^{\mathrm{a}}$ & $56.1^{\mathrm{c}}$ & $61.4^{\mathrm{c}}$ & $65.2^{\mathrm{c}}$ \\
\hline Western wheatgrass & $72.5^{\mathrm{b}}$ & $67.1^{b}$ & $63.3^{\mathrm{b}}$ & $13.6^{\mathrm{ab}}$ & $13.1^{\mathrm{b}}$ & $9.7^{\mathrm{b}}$ & $59.3^{\mathrm{b}}$ & $65.4^{b}$ & $66.4^{\mathrm{bc}}$ \\
\hline Native range & $71.6^{\mathrm{b}}$ & $65.7^{\mathrm{b}}$ & $61.2^{\mathrm{b}}$ & $12.9^{\mathrm{bc}}$ & $12.2^{\mathrm{b}}$ & $8.6^{\mathrm{c}}$ & $61.1^{\mathrm{a}}$ & $69.1^{\mathrm{a}}$ & $68.3^{\mathrm{a}}$ \\
\hline Crested wheatgrass & $72.1^{\mathrm{b}}$ & $65.8^{\mathrm{b}}$ & $62.8^{\mathrm{b}}$ & $12.4^{\mathrm{c}}$ & $11.2^{\mathrm{c}}$ & $9.7^{\mathrm{b}}$ & $58.8^{\mathrm{b}}$ & $65.0^{\mathrm{b}}$ & $67.1^{\mathrm{ab}}$ \\
\hline SE & 0.7 & 0.7 & 0.7 & 0.3 & 0.3 & 0.3 & 0.5 & 0.5 & 0.5 \\
\hline
\end{tabular}

${ }_{1}^{1}$ Least squares means within a column with different superscripts differ $(\mathrm{P}<0.05)$.

${ }^{2}$ IVDMD $=$ in vitro dry matter digestibility, $\mathrm{CP}=$ crude protein, $\mathrm{NDF}=$ neutral detergent fiber 


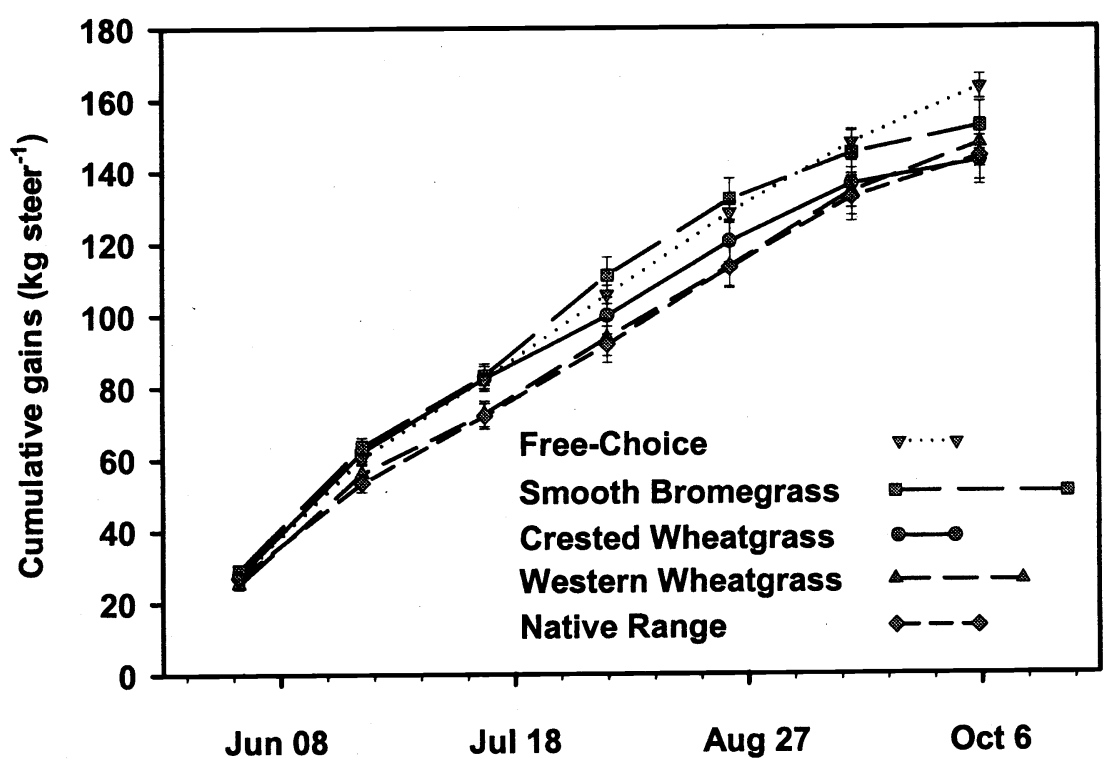

Fig. 1. Average (1995-1997) cumulative weight gains of yearling steers by weighing period ( \pm SE) for free-choice and individual pasture type treatments.

$25 \%$ smooth bromegrass did not provide enough of this high quality forage to meet steer dry matter requirements.

\section{Forage quality}

Statistical analysis of the 1997 chemical composition data for the 4 pasture types indicated an interaction between pasture type and grazing period for NDF and crude protein, therefore data were analyzed by grazing period for all 3 chemical constituents (Table 3). Smooth bromegrass had the highest $(\mathrm{P}<0.05)$ IVDMD all three periods and the highest crude protein (CP) during mid- and late season. Smooth brome also had the lowest NDF during early and mid-season. Crested wheatgrass had the lowest mid-season and native range the lowest late season CP. Native range had significantly higher NDF than other pasture types during early and midseason and was not different $(\mathrm{P}>0.05)$ from crested wheatgrass in late season. The expected seasonal decline in forage quality was also evident (Table 3 ).

\section{Animal behavior}

There was a significant pasture type by period by year interaction for grazing behavior, thus data are presented for different pasture types by period and year. In 1995, when precipitation and cool-season grass production was plentiful, steers tended to spend more time grazing smooth bromegrass and crested wheatgrass (Table $4)$. In the early season, steers spent significantly $(\mathrm{P}<0.10)$ more time grazing smooth bromegrass but, by mid- and late grazing native range and western wheatgrass in the early season. Use of western the growing season of $1995^{1}$. $<0.05$, and $\mathrm{P}<0.15$, respectively. the growing season of $1996^{1}$. wheatgrass appeared to increase from early to late season and was not statistically different than crested wheatgrass the last two periods or smooth bromegrass the final period. Total grazing time as a percentage of observation time increased significantly from early to late season, but grazing time in hours per day ranged from 9.1 to $9.5 \mathrm{hr}$ and was not significantly different among periods (Table 4). Observation time decreased by period as the amount of daylight decreased, thus steers spent a greater proportion of the daylight hours grazing late in the season.

In 1996 , steers spent more $(\mathrm{P}<0.10)$ time grazing smooth bromegrass than native range in the early period, but in mid-season steers spent about equal time grazing smooth bromegrass, crested wheatgrass, and native range (Table 5). In the late period, grazing time among pasture types was not significantly different. For the full season, grazing time was not different $(\mathrm{P}>0.10)$ among pasture types which suggests a more uniform use of all pasture types than in 1995. Grazing time, as a percentage of observation time, again increased progressively during the season, but in 1996, grazing time in hours was

Table 4. Percent of observation time spent grazing pasture types within composite pastures during

\begin{tabular}{lcccc}
\hline \hline Pasture type & Early & Mid & Late & $\begin{array}{c}\text { Season } \\
\text { average }\end{array}$ \\
\hline & $-15.5^{\mathrm{b}}$ & $16.8^{\mathrm{ab}}$ & $23.7^{\mathrm{a}}$ & $18.7^{\mathrm{ab}}$ \\
Crested wheatgrass & $20.8^{\mathrm{a}}$ & $23.2^{\mathrm{a}}$ & $21.6^{\mathrm{a}}$ & $22.2^{\mathrm{a}}$ \\
Smooth bromegrass & $8.6^{\mathrm{c}}$ & $8.6^{\mathrm{b}}$ & $6.5^{\mathrm{b}}$ & $8.0^{\mathrm{b}}$ \\
Native range & $8.1^{\mathrm{c}}$ & $10.1^{\mathrm{b}}$ & $13.6^{\mathrm{ab}}$ & $10.8^{\mathrm{ab}}$ \\
Western wheatgrass & 2.9 & 3.5 & 3.9 & 3.0 \\
SE & $53^{\mathrm{c}}$ & $59^{\mathrm{b}}$ & $65^{\mathrm{a}}$ & 60 \\
Total grazing time (\%) & $9.1^{\mathrm{a}}$ & $9.5^{\mathrm{a}}$ & $9.1^{\mathrm{a}}$ & 9.4 \\
Total grazing time (hr day & -1 & 16.2 & 14.0 & 15.7 \\
Obs. time (hr day $^{-1}$ ) & 17.1 & 16.2 &
\end{tabular}

${ }^{1}$ Early and season-long pasture type means with different superscripts differ at $\mathrm{P}<0.10$ while mid- and late season pasture type means differ at $\mathrm{P}<0.15$. Total grazing time as a percentage and in hours differed among summer periods at $\mathrm{P}$

Table 5. Percent of observation time spent grazing pasture types within composite pastures during

\begin{tabular}{|c|c|c|c|c|}
\hline Pasture type & Early & Mid & Late & $\begin{array}{l}\text { Season } \\
\text { average }\end{array}$ \\
\hline Crested wheatgrass & $11.6^{\mathrm{ab}}$ & $15.0^{\mathrm{a}}$ & $19.9^{\mathrm{a}}$ & $15.3^{\mathrm{a}}$ \\
\hline Smooth bromegrass & $19.8^{\mathrm{a}}$ & $14.3^{\mathrm{a}}$ & $14.2^{\mathrm{a}}$ & $16.5^{\mathrm{a}}$ \\
\hline Native range & $5.8^{\mathrm{b}}$ & $16.1^{\mathrm{a}}$ & $16.1^{\mathrm{a}}$ & $11.9^{\mathrm{a}}$ \\
\hline Western wheatgrass & $12.7^{\mathrm{ab}}$ & $10.2^{\mathrm{b}}$ & $13.8^{\mathrm{a}}$ & $12.5^{\mathrm{a}}$ \\
\hline $\mathrm{SE}$ & 2.1 & 0.7 & 2.9 & 1.9 \\
\hline Total grazing time $(\%)$ & $50^{\mathrm{c}}$ & $56^{\mathrm{b}}$ & $64^{a}$ & 56 \\
\hline Total grazing time $\left(\mathrm{hr} \mathrm{day}^{-1}\right)$ & $8.4^{\mathrm{b}}$ & $8.9^{\mathrm{a}}$ & $9.0^{\mathrm{a}}$ & 8.8 \\
\hline Obs. time $\left(\mathrm{hr}\right.$ day $\left.^{-1}\right)$ & 16.9 & 16.0 & 14.0 & 15.7 \\
\hline
\end{tabular}

${ }^{1}$ Means within columns among species with different superscripts differ $(\mathrm{P}<0.10)$. Total grazing time as a percentage and in hours differed among periods at $\mathrm{P}<0.05$, and $\mathrm{P}<0.15$, respectively. 
Table 6. Percent of observation time spent grazing pasture types within composite pastures during the growing season of $1997^{1}$.

\begin{tabular}{|c|c|c|c|c|}
\hline Pasture type & Early & Mid & Late & $\begin{array}{l}\text { Season } \\
\text { average }\end{array}$ \\
\hline & \multicolumn{4}{|c|}{ 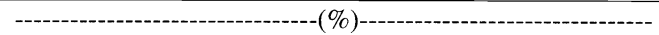 } \\
\hline Crested wheatgrass & $16.2^{\mathrm{b}}$ & $10.8^{\mathrm{b}}$ & $17.5^{\mathrm{a}}$ & $15.0^{\mathrm{b}}$ \\
\hline Smooth bromegrass & $19.7^{\mathrm{a}}$ & $24.7^{\mathrm{a}}$ & $14.8^{\mathrm{ab}}$ & $19.5^{\mathrm{a}}$ \\
\hline Native range & $12.0^{\mathrm{c}}$ & $12.1^{\mathrm{b}}$ & $10.2^{\mathrm{b}}$ & $11.4^{\mathrm{c}}$ \\
\hline Western wheatgrass & $7.0^{\mathrm{d}}$ & $11.0^{\mathrm{b}}$ & $18.8^{\mathrm{a}}$ & $12.6^{\mathrm{c}}$ \\
\hline SE & 1.1 & 2.2 & 2.2 & 0.5 \\
\hline Total grazing time $(\%)$ & $55^{\mathrm{c}}$ & $59^{b}$ & $61^{\mathrm{a}}$ & 58 \\
\hline Total grazing time $\left(\mathrm{hr} \mathrm{day}^{-1}\right)$ & $9.1^{\mathrm{b}}$ & $9.6^{\mathrm{a}}$ & $9.0^{\mathrm{b}}$ & 9.2 \\
\hline Obs. time (hr day $\left.{ }^{-1}\right)$ & 16.6 & 16.3 & 14.8 & 15.8 \\
\hline
\end{tabular}

${ }^{1}$ Early, mid- and all season means with different superscripts differ at $\mathrm{P}<0.10$, while late summer means differ at $\mathrm{P}<$ 0.16 . Total grazing time as a percentage and in hours differed among periods at $P<0.05$, and $P<0.15$, respectively.

slightly but significantly $(\mathrm{P}<0.15)$ lower in early compared to mid- and late season periods (Table 5).

Steers spent the most time $(\mathrm{P}<0.10)$ grazing smooth bromegrass and the least time grazing native range and western wheatgrass during the early period in 1997 (Table 6). In mid-season, steers spent $25 \%$ of the daylight hours grazing smooth bromegrass and between 10 and $12 \%$ of the time grazing on each of the other 3 pasture types. In the late season, steers spent statistically equal time grazing western wheatgrass, smooth bromegrass, and crested wheatgrass, while steers spent less $(\mathrm{P}<0.16)$ time grazing native range than crested or western wheatgrass. Total grazing time in hours per day was greatest $(\mathrm{P}<$ 0.15 ) in mid-season at 9.6 hours. Although smooth bromegrass and crested wheatgrass pastures tended to be favored each year, grazing preference varied by period and year. This variation was undoubtedly related to seasonal changes in plant maturity and forage regrowth patterns. Sheep grazing free-choice season-long on native range, crested wheatgrass, and Russian wildrye rotated themselves among grass species, going first to crested wheatgrass and last to Russian wildrye (Smoliak 1968).

\section{Conclusions}

Steers grazing season-long on composite pastures containing equal areas of crested wheatgrass, western wheatgrass, smooth bromegrass and native range gained as well as steers grazing only smooth bromegrass or western wheatgrass and better than steers grazing native range or crested wheatgrass. Free-choice grazing on composite pastures appeared to improve weight gain in some years more than others, probably depending on the amount and pattern of precipitation which largely dictated forage growth. Over the 3 years, cumulative weight gains of steers grazing smooth bromegrass were highest in early and mid-season while cumulative weight gains of steers on composite pastures were highest in the late season. The cause of this seasonal change is unclear since steers on composite pastures could also graze smooth bromegrass. Lodge (1963) alluded to a similar finding with steers grazing crested wheatgrass and native range in Canada. In 1997, smooth bromegrass forage quality was greatest in the early season, when steers preferred this grass and produced good weight gains. Although composite pastures used in this study did not consistently produce the highest daily gains, the concept seems valid, and many more combinations of forage types and size of plantings could be incorporated into composite pastures to provide cattle with a more consistent season-long high quality diet.

Over-grazing was not a problem in this research. However, in order to prevent over- or under-grazing, areas of each species need to be seeded according to a projected level of use. Plot size of each species needs to be large enough so that plants can progress through a normal maturity cycle without over-grazing, yet small enough to ensure they will be used before they become too mature. If a forage is readily grazed and matures slowly, then a larger area of that species will need to be used compared to a less palatable forage which matures more quickly. Our experience suggests that if stocking rates are not excessive, determining the proper plot size of each forage species is not difficult. Our data as well as the data of Smoliak (1968) indicate that animals will rotate themselves among pasture types as palatability changes, eliminating the need to fence pasture types separately, and reducing the degree of management required compared to rotational grazing.

\section{Literature Cited}

Campbell, J.B. 1952. Farming range pastures. J. Range Manage. 5:252-258.

Campbell, J.B. 1963. Grass-alfalfa versus grass-alone pastures grazed in a repeatedseasonal pattern. J. Range Manage. 16:78-81.

Cherney, D.J.R., M.J. Traxler, and J.B. Robertson. 1997. Use of ANKOM fiber determination systems to determine digestibility. NIRS Forage and Feed Testing Consortium Annual Conference. Madison, Wisc.

Currie, P.O. 1969. Use seeded ranges in your management. J. Range Manage. 22:432-434.

Frischknecht, N.C., L.E Harris, and H.K. Woodward. 1953. Cattle gains and vegetal changes as influenced by grazing treatments on crested wheatgrass. J. Range Manage. 6:151-158.

Goering, H.K. and P.J. Van Soest. 1970. Forage fiber analyses. USDA Agr. Handb. No. 379.

Hofmann, L., R.E. Ries, J.F. Karn, and A.B. Frank. 1993. Comparison of seeded and native pastures grazed from mid-May through September. J. Range Manage. 46:251-254.

Karn, J.F. and L. Hofmann. 1990. Relationships between pasture forage components and fecal chemical composition. J. Range Manage. 43:320-325.

Karn, J.F., R.E. Ries, and L. Hofmann. 1999. Season-long grazing of seeded cool-season pastures in the Northern Great Plains. J. Range Manage. 52:235-240.

Lodge, R.W. 1963. Complementary grazing systems for sandhills of the Northern Great Plains. J. Range Manage. 16:240-244.

Lorenz, R.J. 1977. Complementary grazing system for the Northern Great Plains. p. 2939. In: Proc. The Range Beef Cow Symposium V. Chadron, Neb.

Rogler, G.A., R.J. Lorenz, and H.M. Schaaf. 1962. Progress with grass. N. D. Agr. Exp. Sta. Bull. 439.

Sarvis, J.T. 1941. Grazing investigations on the Northern Great Plains. N. D. Agr. Exp. Sta. Bull. 308.

SAS. 1985. SAS user's guide: Statistics. SAS Inst., Inc. Cary, N.C.

SAS. 1996. SAS system for mixed models. SAS Inst., Inc. Cary, N.C.

Smoliak, S. 1968. Grazing studies on native range, crested wheatgrass, and Russian wildrye pastures. J. Range Manage. 21:47-50.

Williams, R.M. and A.H. Post. 1945. Dryland pasture experiments. Mont. Agr. Exp. Sta. Bull. 431. 